Prepared for the U.S. Fish and Wildlife Service

under an Interagency Agreement with

the U.S. Department of Energy

Contract DE-AC05-76RL01830

\title{
Analysis and Mapping of Vegetation and Habitat for the Sheldon National Wildlife Refuge
}

JD Tagestad

June 2010 


\title{
DISCLAIMER
}

This report was prepared as an account of work sponsored by an agency of the United States Government. Neither the United States Government nor any agency thereof, nor Battelle Memorial Institute, nor any of their employees, makes any warranty, express or implied, or assumes any legal liability or responsibility for the accuracy, completeness, or usefulness of any information, apparatus, product, or process disclosed, or represents that its use would not infringe privately owned rights. Reference herein to any specific commercial product, process, or service by trade name, trademark, manufacturer, or otherwise does not necessarily constitute or imply its endorsement, recommendation, or favoring by the United States Government or any agency thereof, or Battelle Memorial Institute. The views and opinions of authors expressed herein do not necessarily state or reflect those of the United States Government or any agency thereof.

\author{
PACIFIC NORTHWEST NATIONAL LABORATORY \\ operated by \\ BATTELLE \\ for the \\ UNITED STATES DEPARTMENT OF ENERGY \\ under Contract DE-AC05-76RL01830
}

Printed in the United States of America
Available to DOE and DOE contractors from the Office of Scientific and Technical Information,
P.O. Box 62, Oak Ridge, TN 37831-0062;
ph: (865) 576-8401
fax: (865) 576-5728
email: reports@adonis.osti.gov

\author{
Available to the public from the National Technical Information Service, \\ U.S. Department of Commerce, 5285 Port Royal Rd., Springfield, VA 22161 \\ ph: (800) 553-6847 \\ fax: (703) 605-6900 \\ email: orders@ntis.fedworld.gov \\ online ordering: http://www.ntis.gov/ordering.htm
}

This document was printed on recycled paper. 


\section{Analysis and Mapping of Vegetation and Habitat for the Sheldon National Wildlife Refuge}

JD Tagestad

June 2010

Prepared for

the U.S. Fish and Wildlife Service under an Interagency Agreement with the U.S. Department of Energy Contract DE-AC05-76RL01830

Pacific Northwest National Laboratory Richland, Washington 99352 


\begin{abstract}
The Lakeview, Oregon, office of the U.S. Fish and Wildlife Service (USFWS) contracted Pacific Northwest National Laboratory to classify vegetation communities on the Sheldon National Wildlife Refuge in northeastern Nevada. The objective of the mapping project was to provide USFWS refuge biologists and planners with detailed vegetation and habitat information that can be referenced to make better decisions regarding wildlife resources, fuels and fire risk, and land management.

This report describes the datasets and methods used to develop vegetation cover type and shrub canopy cover maps for the Sheldon National Wildlife Refuge. The two map products described in this report are 1) a vegetation cover classification that provides updated information on the vegetation associations occurring on the refuge and 2) a map of shrub canopy cover based on high-resolution images and field data.
\end{abstract}




\section{Contents}

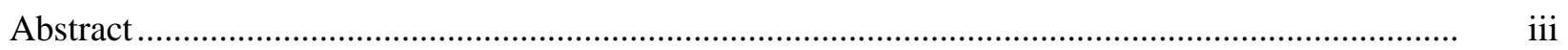

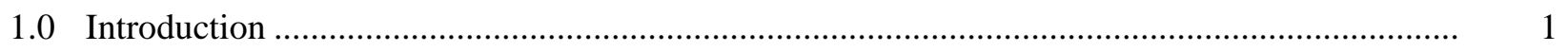

2.0 Development of Improved Vegetation and Habitat Maps ..................................................... 1

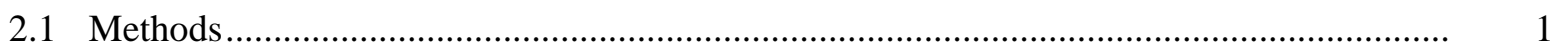

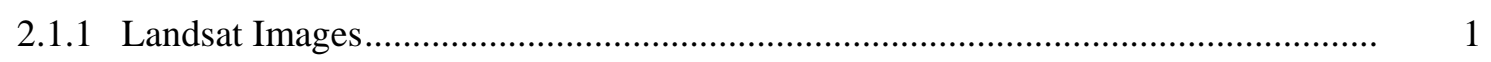

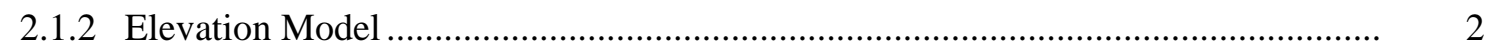

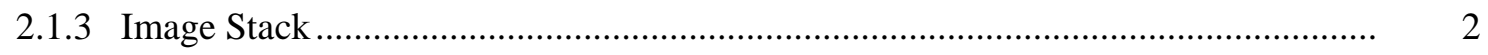

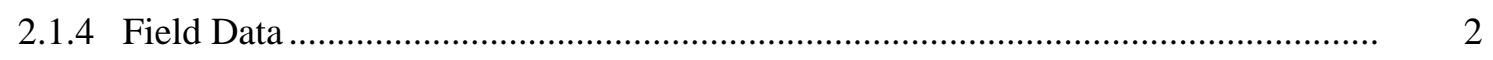

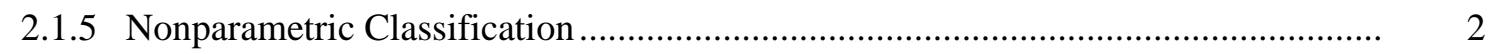

2.1.6 Post-Classification Steps .................................................................................. 3

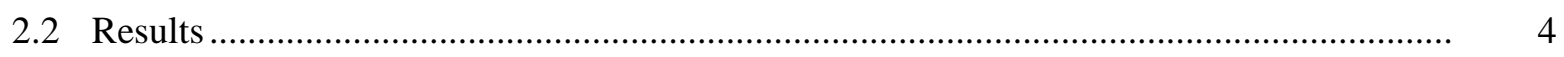

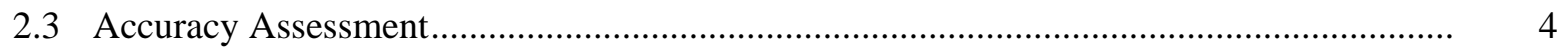

3.0 Shrub Canopy Model Development ........................................................................... 8

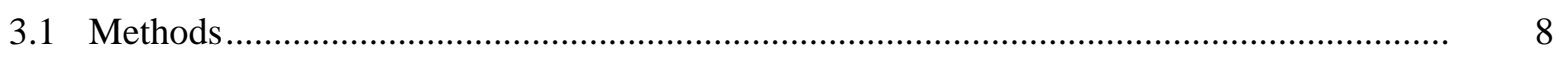

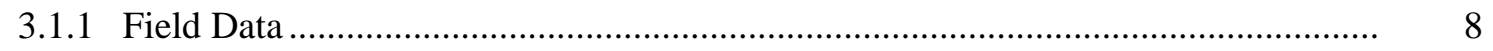

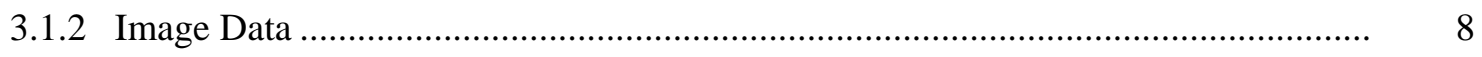

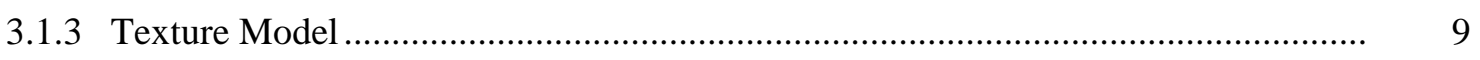

3.1.4 Regression Model............................................................................................... 10

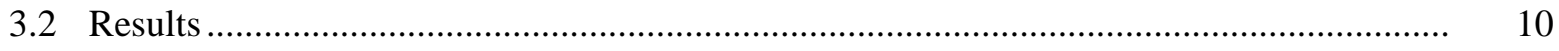

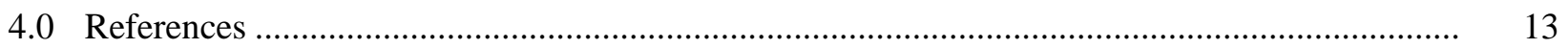




\section{Figures}

1 Vegetation Map of Sheldon National Wildlife Refuge ............................................................... 5

2 Three-Band Color Image of an Area of Variable Shrub Cover .................................................. 9

3 Band 2 Texture Image of an Area of Variable Shrub Cover .................................................... 10

4 Relationship Between Image Texture and Field-Measured Shrub Canopy Cover ...................... 11

5 Final Shrub Canopy Map Shown with Roads and Approximate Refuge Boundary.................... 12

\section{Tables}

1 Number of Field Sites for Each Vegetation Cover Type .......................................................... 3

2 Detailed Vegetation Description..................................................................................... 5

3 General Vegetation Descriptions with National Vegetation Classification Crosswalk ................ 6

$4 \quad$ Sheldon Refuge Vegetation Map Error Matrix .......................................................................... 7

5 Sheldon Vegetation Map Table of Users and Producers Accuracy ............................................ 7 


\subsection{Introduction}

The U.S. Fish and Wildlife Service (USFWS), Lakeview, Oregon, contracted Pacific Northwest National Laboratory (PNNL) to classify vegetation communities on the Sheldon National Wildlife Refuge in northeastern Nevada. The objective of the mapping project was to provide USFWS refuge biologists and planners with detailed vegetation and habitat information that can be referenced to make better decisions regarding wildlife resources, fuels and fire risk, and land management.

This report describes the datasets and methods PNNL used to develop vegetation cover type and shrub canopy cover maps for the Sheldon National Wildlife Refuge. Section 2 gives the details of a vegetation cover classification that provides updated information on the vegetation associations occurring on the refuge. Section 3 describes a map of shrub canopy cover based on high-resolution images and field data. References cited in this report are listed in Section 4.

\subsection{Development of Improved Vegetation and Habitat Maps}

In this section, we describe the datasets and methods used to develop a baseline vegetation classification for the Sheldon National Wildlife Refuge using satellite imagery acquired in 2003 and ecologically precise ground truth data collected by the USFWS and PNNL. The imagery was classified to delineate vegetation associations (dominant overstory/dominant understory) where spectral differences were sufficient to discriminate vegetation at that level of detail. Every attempt was made to retain the finest ecological description in the final map, but when spectral characteristics were insufficient, we attempted to identify the dominant species or species mix, including subspecies of sagebrush. The classification routine applied was a nonparametric clustering scheme. Post-classification editing was performed using local knowledge and ancillary datasets.

\subsection{Methods}

\subsubsection{Landsat Images}

The study used three Landsat 7 images from 2003 from the Multi-Resolution Land Characteristics Consortium (MRLC) archive (www.mrlc.gov). These images were from Path/Row 43/31 collected on June 6, July 8, and October 12. The images were geometrically and radiometrically corrected using standard methods at the U.S. Geological Survey (USGS) Earth Resources Observation and Science (EROS) using the National Landsat Archive Production System (NLAPS). Possible geo-location errors due to terrain effect were corrected using the 1-arcsecond National Elevation Dataset (NED). Bands 1 to 5 and 7 were resampled to a 30-m spatial resolution using the cubic convolution method.

The raw images were delivered with a pixel value as a digital number (DN), which relates to reflected radiance via published band-specific coefficients. To further standardize the impact of illumination geometry, the MRLC first converts the DN images to at-satellite radiance (watts per meter squared) by applying the coefficients. These radiance values are multiplied by pi and earth-sun distance, and the sum 
is divided by exo-atmospheric radiation and the cosine of the zenith angle. To store the reflectance pixel values as 8-bit images, the reflectance value was scaled by 400 (Homer et al. 2004).

The reflectance images were converted to brightness, greenness, wetness images, based on the work from Crist and Cicone (1984). This transform uses coefficients for all six bands of the Landsat data to compute the relative influence of the brightness, greenness, and wetness components of each pixel. These images were scaled by a factor of 10000 and stored as 16-bit integer images.

\subsubsection{Elevation Model}

We acquired the National Elevation Dataset for the Sheldon refuge and surrounding area from the USGS Seamless server (http://seamless.usgs.gov). The elevation data were used to derive a shaded relief map to be used as the analog for solar input. This shaded relief was calculated using ERDAS Imagine with solar elevation and azimuth values set to 60 and 225 degrees, respectively. The solar geometry was used to approximate the "average" solar warming over the growing season. The resultant image has values ranging from 0 to 1 , where 0 is no direct sunlight at the defined solar geometry and 1 is direct incident light, perpendicular to land surface. This layer was used to approximate a range of topographic moisture conditions from wet to dry based on the intensity of solar energy. The shaded relief pixel data were scaled by 10000 and stored as 16-bit integers. The elevation data also were used to derive a topographic moisture index, following techniques defined by Bohner (2002). The moisture index is based on the digital elevation model (DEM) and uses region analysis to determine where water will accumulate naturally (and, conversely, where it will come from and where the soil should be drier).

\subsubsection{Image Stack}

The brightness, wetness, and greenness images derived from the Landsat images ( 3 dates $\times 3$ derivatives $=9$ images) were combined with the elevation and shaded relief maps ( 2 images) in ERDAS Imagine using a layer stack function to create an 11-band image stack.

\subsubsection{Field Data}

Field data were collected by USFWS crews in June and July 2008. Data collection was performed by selecting representative areas of specific cover types and collecting Global Positioning System (GPS) information, photographs, and notes on cover type and site characteristics. This vegetation point information was entered into ArcGIS and buffered by $60 \mathrm{~m}$ to align with multiple pixels in the associated image. A total 130 ground truth polygons were used. The number of field sites for each of the vegetation cover types is shown in Table 1.

\subsubsection{Nonparametric Classification}

Remote sensing classification is dependent on identifying unique spectral signatures for each class of cover type. Traditional supervised classification techniques generally aggregate vegetation spectral signatures to a simple statistical value (e.g., the mean). The result is a classification that processes very rapidly because each pixel is compared to this mean and is classified as the pixel type to which it most closely matches. Provided that the spectral data are distributed normally, this is an effective approach. However, it is often observed that many classes exhibit significant non-normal spectral distribution 
Table 1. Number of Field Sites for Each Vegetation Cover Type

\begin{tabular}{lc}
\hline Vegetation Cover Type & $\begin{array}{c}\text { Field Sites } \\
(N)\end{array}$ \\
\hline Barren & 2 \\
\hline Columbia Plateau Low Sagebrush Steppe & 18 \\
\hline Inter-Mountain Basins Big Sagebrush Shrubland & 25 \\
\hline Inter-Mountain Basins Cliff and Canyon & 3 \\
\hline Inter-Mountain Basins Greasewood Flat & 13 \\
\hline Inter-Mountain Basins Juniper Savanna & 5 \\
\hline Inter-Mountain Basins Mixed Salt Desert Scrub & 6 \\
\hline Inter-Mountain Basins Montane Sagebrush Steppe & 31 \\
\hline Inter-Mountain Basins Mountain Mahogany Woodland and & 6 \\
Shrubland & 2 \\
\hline Inter-Mountain Basins Playa & 6 \\
\hline Inter-Mountain Basins Semi-Desert Grassland & 6 \\
\hline North American Arid West Emergent Marsh & 3 \\
\hline Northern Rocky Mountain Lower Montane-Foothill Deciduous & 2 \\
\hline Open Water & 2 \\
\hline Rocky Mountain Aspen Forest and Woodland & \\
\hline
\end{tabular}

(Knick et al. 1997) for some of the spectral variables (e.g., shaded relief, greenness). If these training site pixels are entered into a standard supervised classification (maximum likelihood or minimum distance), the results likely will be unacceptable because the mean of a non-normal distribution does not accurately represent the population data values. For this reason, PNNL developed a simple nonparametric classification routine. The nonparametric approach does not integrate all signatures for a cover type but allows a cover type to be represented with many different signatures. The nonparametric approach does not infer anything about the distribution of the data but simply compares every known pixel to every unknown pixel in the image. This is an extremely processor-intensive operation, so the custom software was written to operate on a multiprocessor computer cluster.

The output from the classifier is a two-layer raster dataset in which layer 1 represents the field data class that most closely matches the pixel (e.g., Big Sagebrush, Salt Desert Shrub, Greasewood). Layer 2 of the output image represents the spectral Euclidean distance between the input pixel and the most closely associated pixel. Layer 1 was used as the vegetation map.

\subsubsection{Post-Classification Steps}

The output classification underwent a minimal amount of post-classification editing, both manual and automated, via a Boolean model. The Boolean model had as inputs the output classification from the nonparametric model, topographic elevation, and topographic wetness (from the index described above). This information was used to address three primary errors:

- identification of areas likely dominated by Basin Big Sagebrush that were mapped as Wyoming Big Sagebrush 
- [IF “Wyoming Big Sagebrush” AND Topographic Moisture Index > 15, THEN “Basin Big Sagebrush"]

- $\quad$ [IF "Mountain Big Sagebrush" AND Elevation < 1600 AND Topographic Moisture Index > 15, THEN “Basin Big Sagebrush”]

- [IF “Mountain Big Sagebrush” AND Elevation > 1600 AND < 1900 AND Topographic Moisture Index > 17, THEN “Basin Big Sagebrush”]

- identification of Emergent Vegetation (willows) erroneously classified as Aspen, Juniper, or Mountain Mahogany.

- [IF “Mountain Mahogany, Juniper or Aspen” AND Elevation < 1900 AND Topographic Moisture Index > 16, THEN “Emergent Marsh”]

- identification of Perennial Grassland erroneously mapped as Wet Meadow.

- [IF “Wet Meadow” AND Topographic Moisture Index < 11, THEN “Perennial Grassland”].

Based on notes from USFWS vegetation specialists, manual edits were applied to the map using the ERDAS Imagine editing tool. The manual edits were applied to two locations to add Mountain Mahogany (304860, 4625000 and 315738, 4607485).

\subsection{Results}

The map that resulted is shown in Figure 1. The map attribute table consists of three levels of classification detail (Tables 2 and 3) starting with very specific National Vegetation Classification (NVC) descriptions lumping to general vegetation descriptions.

\subsection{Accuracy Assessment}

The overall accuracy of the map was 84\%, with most of the error due to confusion between different shrub types (Low Sagebrush, Mountain Sagebrush, Big Sagebrush, and Salt Desert Scrub). In general, the overall map accuracy value provides insight into how well the map portrays reality.

Accuracy assessment data were collected during summer 2009 using techniques identical to those for collecting ground truth data. These points were assigned a cover type consistent with the map categories. It should be noted that the assignment of ground truth class is not without potential for error, and as thematic precision increases (more classes), so does potential for class assignment error. For example, if a field observer collects a ground truth point in an area having equal proportions of Low Sage and Mountain Big Sage, a decision must be made as to which map class would provide the best fit. If the observer assigns the point as Low Sage and the map identifies the point as Mountain Big Sage, an error will be noted. While this does give useful information, it is not an error per se, in that the vegetation class assignment could have easily gone the other way (field point categorized as Mountain Big Sage). The assessment points were placed over the map using geographic information system (GIS) data, and the mapped vegetation type at the location was recorded. Additionally, we recorded the vegetation type for the immediately adjacent pixels. To create the error matrix shown in Table 4, we counted the vegetation as mapped correctly if the vegetation at or adjacent to the pixel of intersection matched the ground truth class. This "fuzzy matching" accounts for the spatial error in pixel location, which can be up to 30 meters off. The error matrix results are organized in Table 4. 


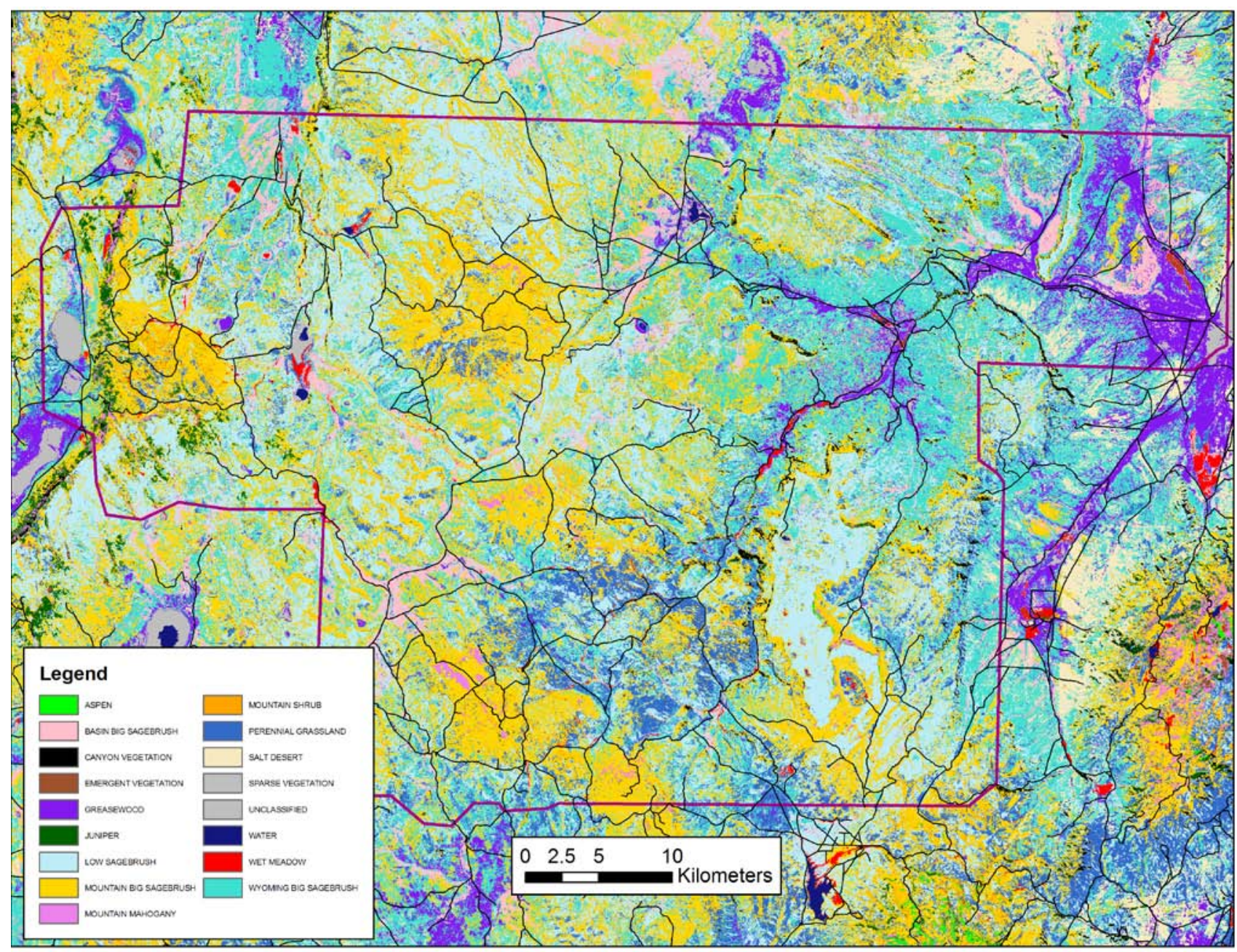

Figure 1. Vegetation Map of Sheldon National Wildlife Refuge

Table 2. Detailed Vegetation Description

\begin{tabular}{ll}
\hline National Vegetation Classification Description & \multicolumn{1}{c}{ NVC Alias } \\
\hline Barren & Sparse Vegetation \\
\hline Columbia Plateau Low Sagebrush Steppe & Low Sagebrush \\
\hline Inter-Mountain Basins Big Sagebrush Shrubland & Wyoming Big Sagebrush \\
\hline Inter-Mountain Basins Cliff and Canyon & Canyon Vegetation \\
\hline Inter-Mountain Basins Greasewood Flat & Greasewood \\
\hline Inter-Mountain Basins Juniper Savanna & Juniper \\
\hline Inter-Mountain Basins Mixed Salt Desert Scrub & Salt Desert \\
\hline Inter-Mountain Basins Montane Sagebrush Steppe & Mountain Big Sagebrush \\
\hline Inter-Mountain Basins Mountain Mahogany Woodland and Shrubland & Mountain Mahogany \\
\hline Inter-Mountain Basins Playa & Sparse Vegetation \\
\hline
\end{tabular}


Table 2. (contd)

\begin{tabular}{ll}
\hline National Vegetation Classification Description & \multicolumn{1}{c}{ NVC Alias } \\
\hline Inter-Mountain Basins Semi-Desert Grassland & Perennial Grassland \\
\hline Basin Big Sagebrush & Basin Big Sagebrush \\
\hline Rocky Mountain Ponderosa Pine Woodland & Conifer \\
\hline Rocky Mountain Subalpine-Montane Mesic Meadow & Wet Meadows \\
Northern Rocky Mountain Lower Montane-Foothill Deciduous Shrubs & Mountain Shrub \\
Open Water & Water \\
Rocky Mountain Aspen Forest and Woodland & Aspen \\
\hline North American Arid West Emergent Marsh & Emergent Vegetation \\
Invasive Annual Forbland & Invasive Forbs \\
Invasive Annual Grassland & Invasive Annual \\
\hline
\end{tabular}

Table 3. General Vegetation Descriptions with National Vegetation Classification Crosswalk

\begin{tabular}{ll}
\hline $\begin{array}{l}\text { General Vegetation } \\
\text { Description }\end{array}$ & \multicolumn{1}{c}{ National Vegetation Classification } \\
\hline Aspen & Rocky Mountain Aspen Forest and Woodland \\
\hline Big Sagebrush & $\begin{array}{l}\text { Basin Big Sagebrush } \\
\text { Inter-Mountain Basins Big Sagebrush Shrubland }\end{array}$ \\
\hline Canyon Vegetation & Inter-Mountain Basins Cliff and Canyon \\
\hline Conifer & Rocky Mountain Ponderosa Pine Woodland \\
\hline Invasive & $\begin{array}{l}\text { Invasive Annual Forbland } \\
\text { Invasive Annual Grassland }\end{array}$ \\
\hline Juniper & Inter-Mountain Basins Juniper Savanna \\
\hline Low Sagebrush & Columbia Plateau Low Sagebrush Steppe \\
\hline Mountain Big Sagebrush & $\begin{array}{l}\text { Inter-Mountain Basins Montane Sagebrush Steppe } \\
\text { Northern Rocky Mountain Lower Montane-Foothill Deciduous Shrubs }\end{array}$ \\
\hline Mountain Mahogany & Inter-Mountain Basins Mountain Mahogany Woodland and Shrubland \\
\hline Perennial Grassland & Inter-Mountain Basins Semi-Desert Grassland \\
\hline Salt Desert & $\begin{array}{l}\text { Inter-Mountain Basins Greasewood Flat } \\
\text { Inter-Mountain Basins Mixed Salt Desert Scrub }\end{array}$ \\
\hline Sparse Vegetation & $\begin{array}{l}\text { Barren } \\
\text { Inter-Mountain Basins Playa }\end{array}$ \\
\hline Water & Open Water \\
\hline Wet Meadow & $\begin{array}{l}\text { North American Arid West Emergent Marsh } \\
\text { Rocky Mountain Subalpine-Montane Mesic Meadow }\end{array}$ \\
\hline
\end{tabular}


Table 4. Sheldon Refuge Vegetation Map Error Matrix

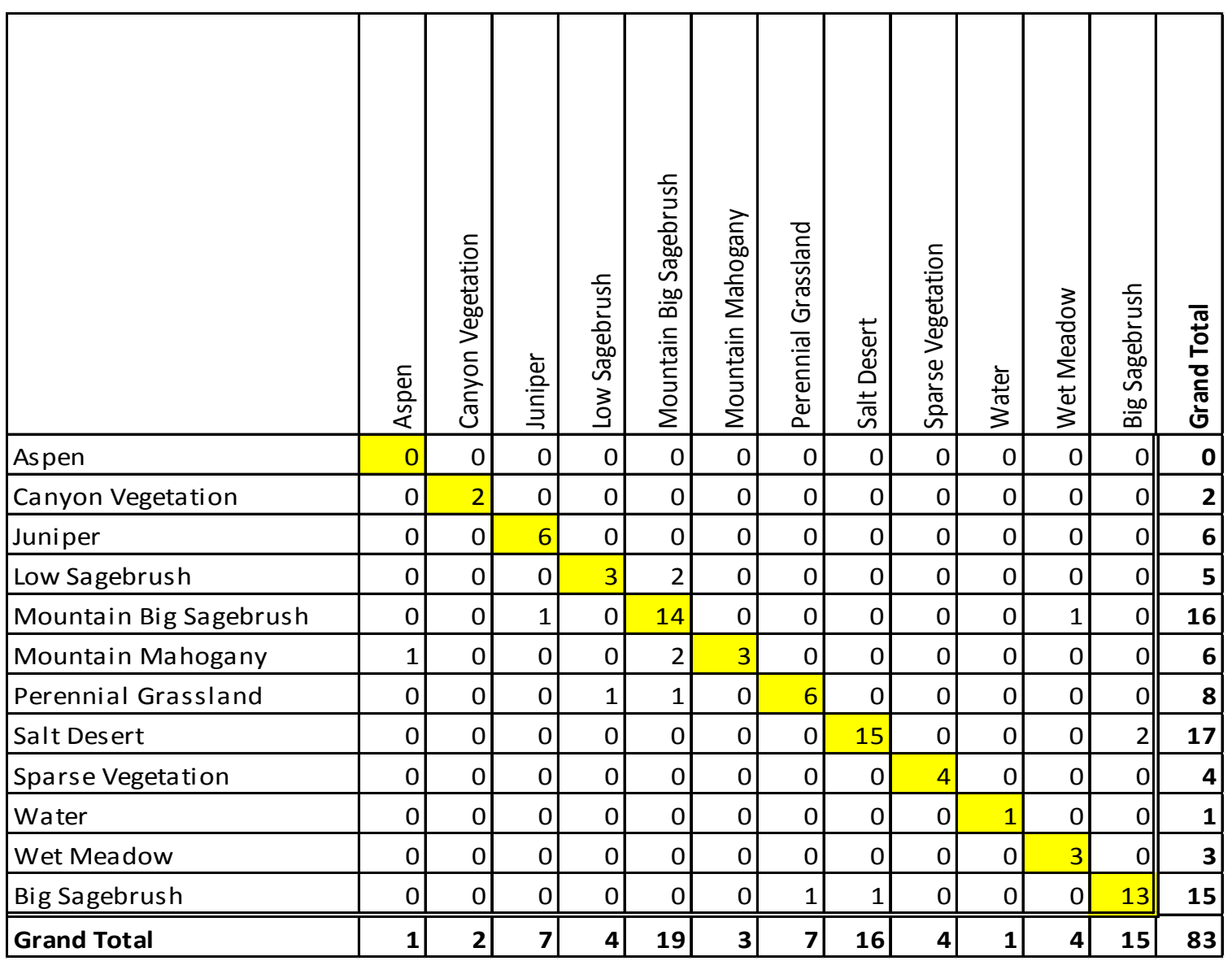

Table 5. Sheldon Vegetation Map Table of Users and Producers Accuracy

\begin{tabular}{lcc}
\hline Vegetation Type & Producer Accuracy (\%) & User Accuracy (\%) \\
\hline Aspen & 100.00 & 100.00 \\
Canyon Vegetation & 100.00 & 100.00 \\
Juniper & 85.71 & 100.00 \\
\hline Low Sagebrush & 75.00 & 60.00 \\
\hline Mountain Big Sagebrush & 73.68 & 87.50 \\
\hline Mountain Mahogany & 100.00 & 50.00 \\
Perennial Grassland & 85.71 & 75.00 \\
\hline Salt Desert & 93.75 & 88.24 \\
Sparse Vegetation & 100.00 & 100.00 \\
Water & 100.00 & 100.00 \\
Wet Meadow & 75.00 & 100.00 \\
Wyoming Big Sagebrush & 86.67 & 86.67 \\
\hline
\end{tabular}




\subsection{Shrub Canopy Model Development}

The relative amount and distribution of shrub canopy cover in rangelands is critical information for land managers, fire modelers, wildlife biologists, and ecologists, but determining the spatial extent and relative quantity of shrublands across the landscape can be very difficult. The specific purpose of this study was to test automated methods for characterizing shrub canopy cover (distribution and density) using several types of fine-scale image data. We employed methods using shrub canopy field measurements with high-resolution land imagery to produce a map layer quantifying shrub canopy cover.

Developing capabilities to map shrub canopy cover in the shrub-steppe has been a challenge for the remote sensing community. Current methods for measuring shrub canopy cover require intensive field measurements. Transect or plot sampling for canopy cover can provide useful data from discrete locations but is insufficient for developing a landscape-level understanding of shrub cover and distribution. In addition, the patterns of shrub canopy cover and distribution are discerned more easily from above than from on the ground. Large-area canopy analysis generally has required field data, local knowledge, and photo interpretation. In contrast, we used limited field data with high-resolution aerial or satellite imagery and GIS technology to develop and apply methods to create fine-scale shrub canopy maps.

\subsection{Methods}

\subsubsection{Field Data}

Field plots were selected within the Sheldon National Wildlife Refuge. The field crew was instructed to distribute the field data to represent the variability in shrub canopy cover across the study area. Plots were placed in selected cover types that represented the local variation in canopy from sparse to dense cover. Field plots measuring $10 \mathrm{~m} \times 10 \mathrm{~m}$ were laid out with one axis oriented to true north. Within each square plot, we measured shrub height, widest canopy measurement, and canopy measure perpendicular to the widest measurement. Aerial canopy oval areas were calculated from the widest and perpendicular measurements for each shrub rooted within the plot heights, and widths were recorded to the nearest decimeter. Ocular estimates of the percentage live foliar canopy and percentage dead foliar canopy also were recorded. Total canopy cover was calculated by summing the oval areas for each rooted shrub and any canopy of shrubs not rooted in the plot that extended over the boundary into the plot. The total is expressed as a percentage of the $100-\mathrm{m}^{2}$ plot area and adjusted for the amount of dead foliar canopy. Digital photographs were taken of the plot. The field data plot information was converted to digital GIS files using the differentially-corrected GPS corner coordinates.

\subsubsection{Image Data}

The fine-scale image was acquired from the 2006 1-m National Agricultural Imagery Program (NAIP) data. The NAIP is designed to acquire 1-m or 2-m resolution images, natural color, and/or color infrared images at peak growing season. The imagery is corrected using USGS digital ortho quarter quads (DOQQs) as a reference, to an absolute accuracy of $5 \mathrm{~m}$ for the 1-m product and $10 \mathrm{~m}$ for the 2-m product. The image products come in two basic formats. The Compressed County Mosaic (CCM) product is a mosaic generated by entering all the individual tiles for an entire county. This product is 
stored in MrSID compressed format with a compression ratio of 15:1 for the 2005 and 2006 data or 50:1 for the earlier products. The individual DOQQ areas (3.75-minute $\times 3.75$-minute plus a 300 -m buffer) are distributed in GeoTIFF format. For this study, we relied on the GeoTIFF product to provide the fine spatial detail to our algorithm because the MrSID compression affects the apparent image texture.

\subsubsection{Texture Model}

Texture, as it applies to image interpretation, is defined as the visual impression of coarseness or smoothness caused by the variability or uniformity of image tone or color (Avery and Berlin 1992). The texture methods utilize the apparent roughness in the visible surface due to drastic changes in brightness between adjacent pixels.

Our approach builds on a PNNL-developed texture ratio technique that has proven useful for road extraction. The texture model reduces the color signal in the image and maximizes the texture signal. This analysis technique capitalizes on the mutual information between results of smoothing the image with low-pass filters of two sizes (for example, $3 \times 3$ pixels and $5 \times 5$ pixels). Figures 2 and 3 show the effect of the texture filter transforming the visible image to the texture domain.

The texture ratio is calculated via Equation (1):

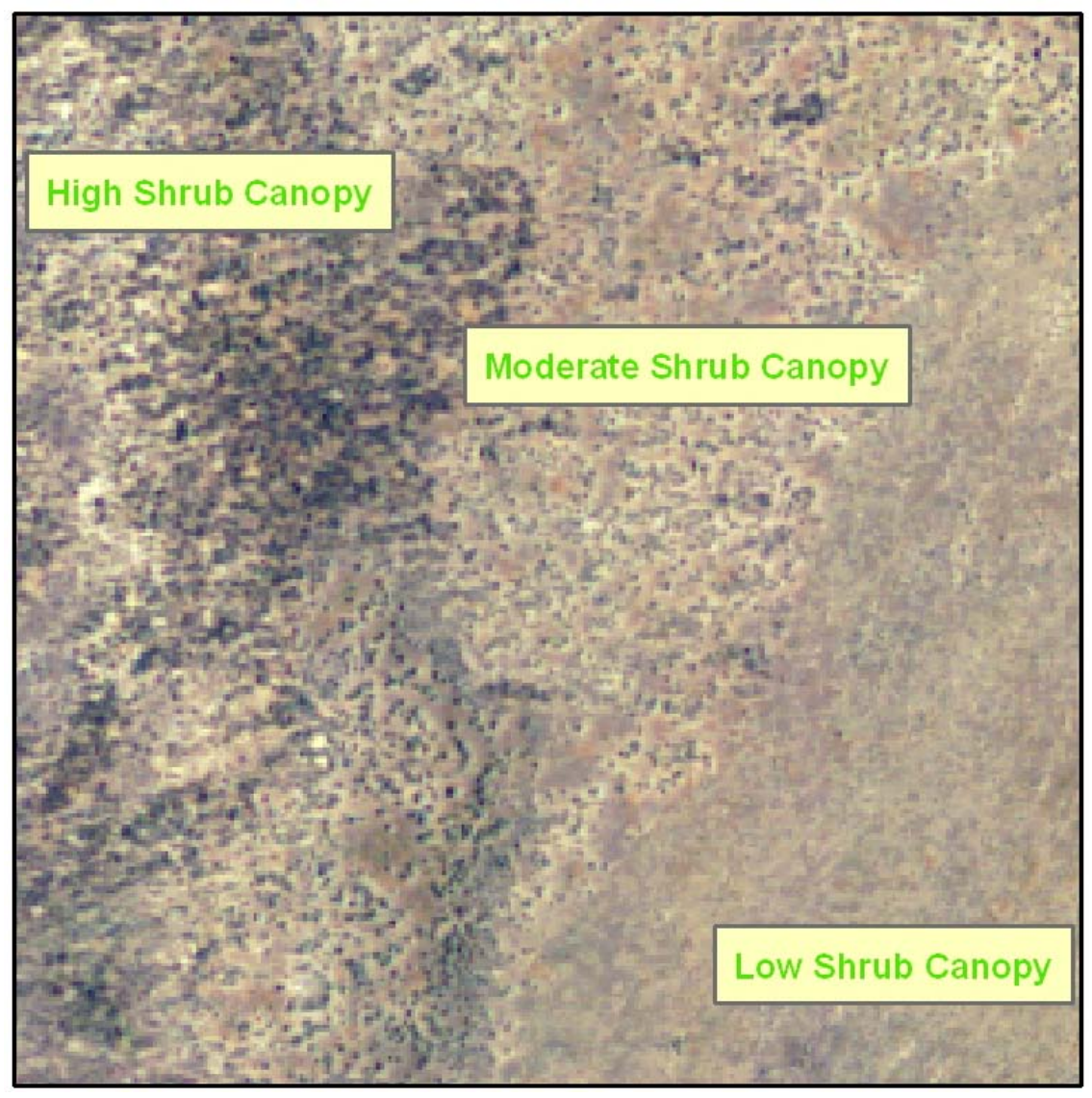

Figure 2. Three-Band Color Image of an Area of Variable Shrub Cover 


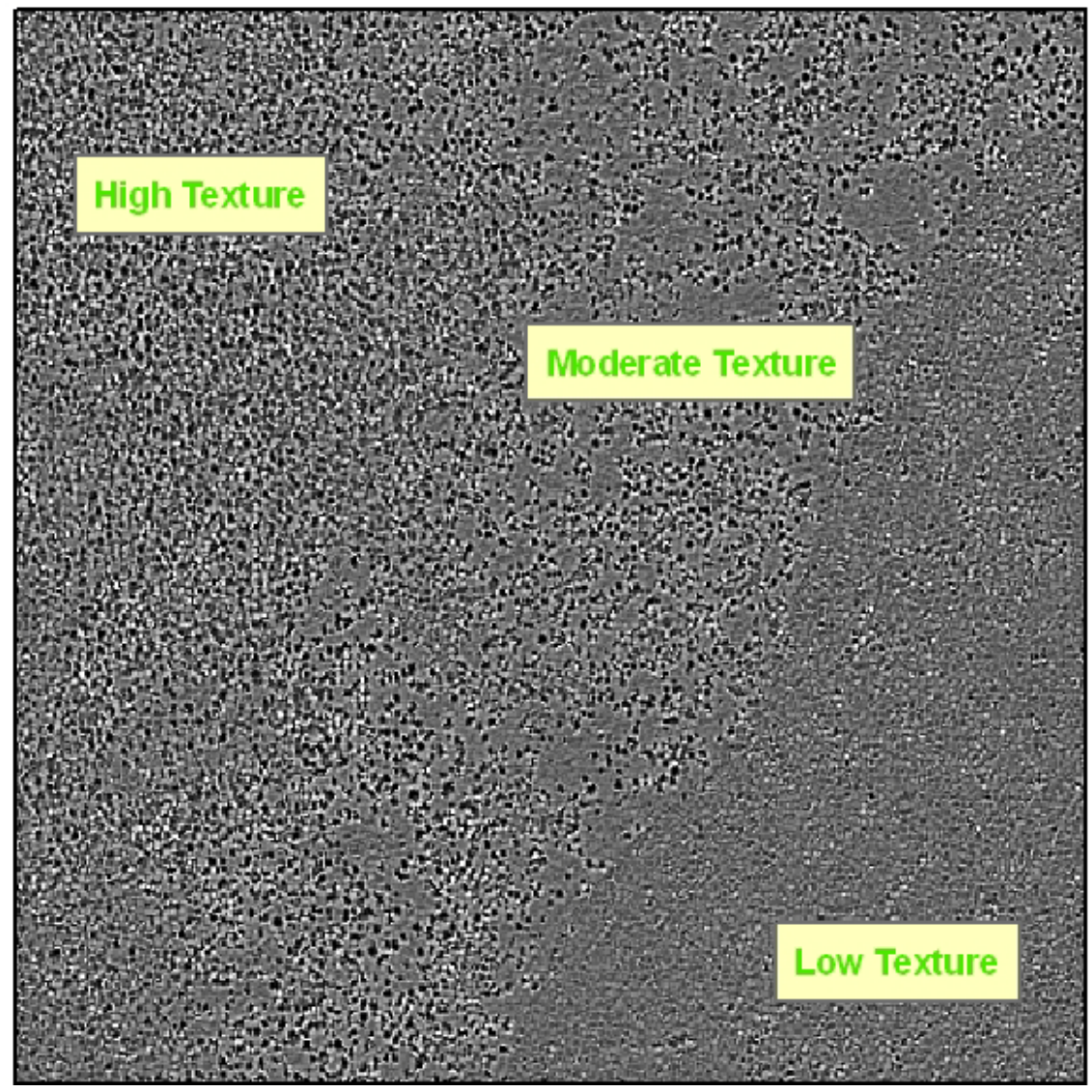

Figure 3. Band 2 Texture Image of an Area of Variable Shrub Cover

\subsubsection{Regression Model}

To develop a simple linear regression relationship between shrub canopy cover and image texture, the field-measured shrub canopy cover in each plot was compared to the corresponding texture ratio values for pixels representing that plot (see Figure 4).

From this relationship, we derived a model to map image texture to canopy cover. This model was then applied to the texture image to create a map of continuous canopy cover (from $0 \%$ to $60 \%$ cover) at 5 -m resolution. Areas of extremely high texture value were used as a mask for trees (shrub canopy set to zero).

\subsection{Results}

Vegetation specialists from the USFWS have provided feedback on the canopy map (Figure 5), and there appears to be very good correspondence between map and conditions in the field. The canopy map does appear to be representing low sage quite well, despite the low stature of the shrub. There appears to be a general overestimation of canopy in areas with very bright soil background. 


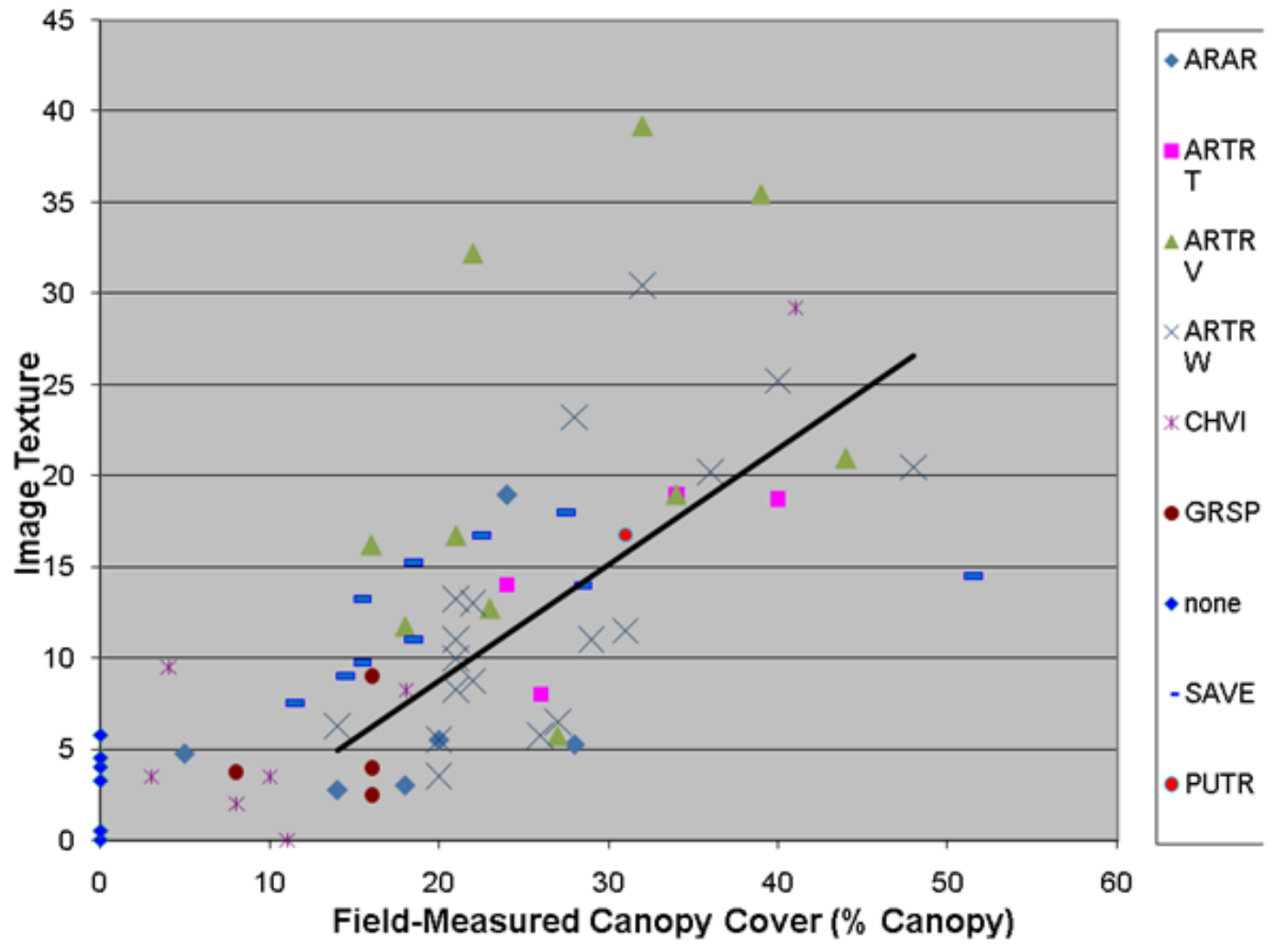

Figure 4. Relationship Between Image Texture and Field-Measured Shrub Canopy Cover 


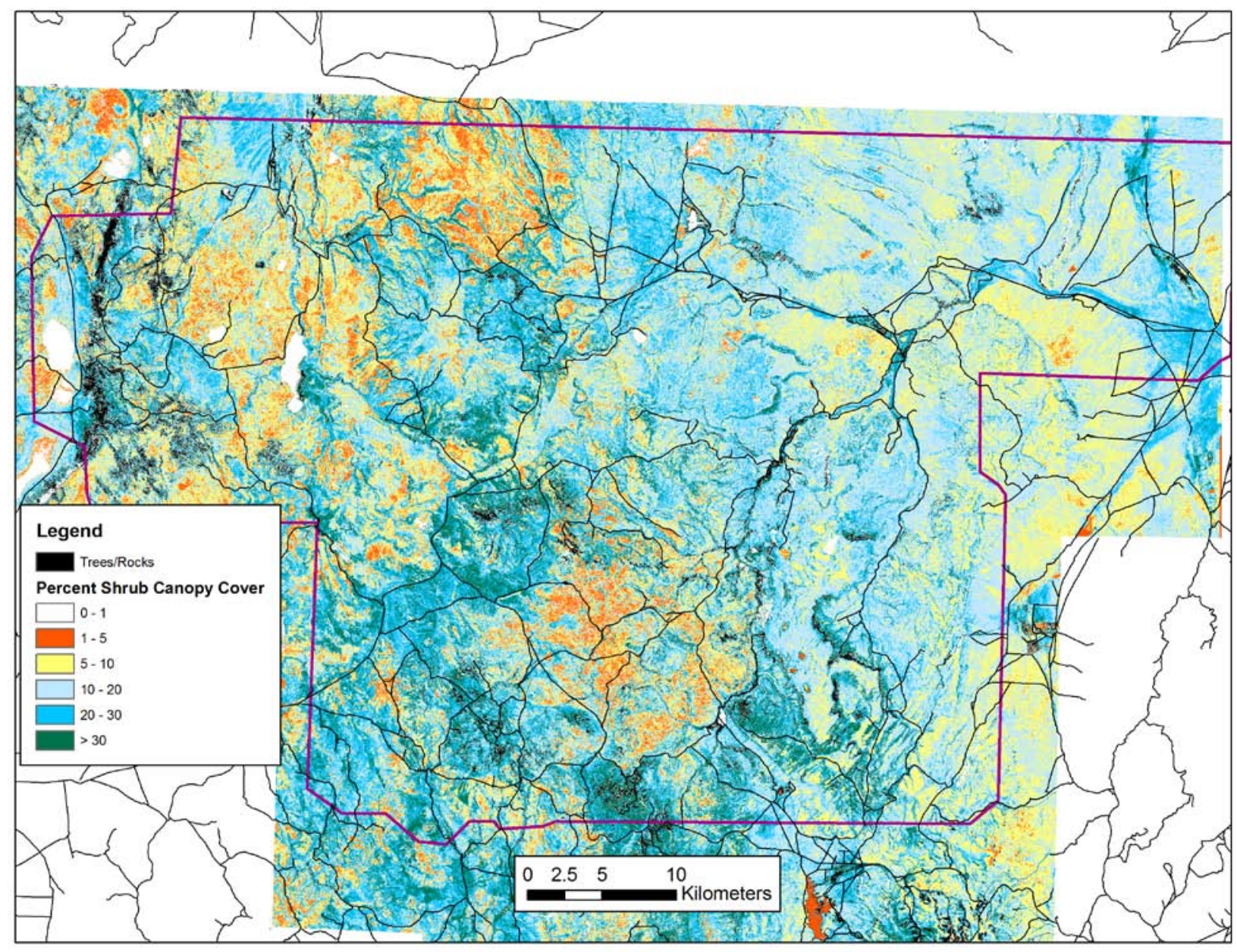

Figure 5. Final Shrub Canopy Map Shown with Roads and Approximate Refuge Boundary 


\subsection{References}

Avery TE and GL Berlin. 1992. Fundamentals of Remote Sensing and Airphoto Interpretation. Macmillan Publishing Company, New York.

Bohner J, R Kothe, O Conrad, J Gross, A Ringler, and T Selige. 2002. Soil regionalisation by means of terrain analysis and process parameterization. Soil Classification 2001. EUR 20398 EN, The European Soil Bureau, Joint Research Centre, Ispra, Italy.

Crist EP and RC Ciccone. 1984. A physically-based transformation of Thematic-Mapper data - the TM tasseled cap. IEEE Transactions in Geoscience and Remote Sensing GE-22:256-263.

Homer C, C Huang, L Yang, B Wylie, and M Coan. 2004. Development of a 2001 national land-cover database for the United States. Photogrammetric Engineering \& Remote Sensing 70(7):829-840.

Knick S, J Rotenberry, and T Zarriello. 1997. Supervised classification of Landsat Thematic Mapper imagery in a semi-arid rangeland by nonparametric discriminant analysis. Photogrammetric Engineering and Remote Sensing 63:79-86. 


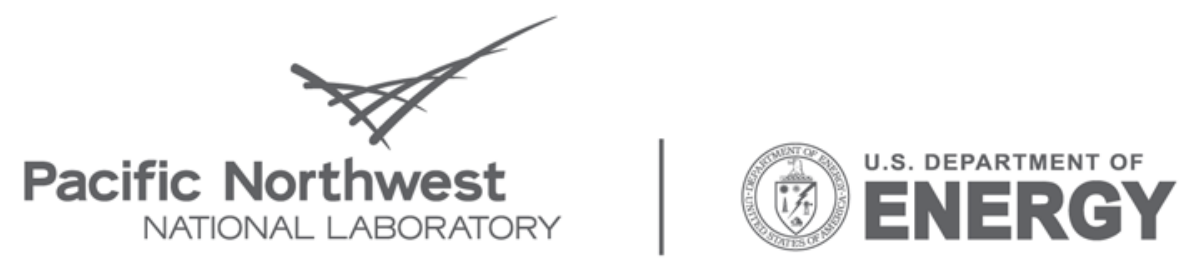

Proudly Operated by Battelle Since 1965

902 Battelle Boulevard

P.O. Box 999

Richland, WA 99352

1-888-375-PNNL (7665)

www.pnl.gov 